\title{
The Case for a Construction Industry Council in Ghana
}

\author{
*Joseph Kwame Ofori-Kuragu, De-Graft Owusu-Manu and \\ Joshua Ayarkwa
}

\begin{abstract}
Published online: 21 December 2016
To cite this article: Joseph Kwame Ofori-Kuragu, De-Graft Owusu-Manu and Joshua Ayarkwa. (2016). The case for a construction industry council in Ghana. Journal of Construction in Developing Countries, 21(2): 131-149. https://dx.doi.org/10.21315/jcdc2016.21.2.7.

To link to this article: https://dx.doi.org/10.21315/jcdc2016.21.2.7

Abstract: The Ghanaian construction industry faces major problems that undermine its potential and contribution to overall national development. There is a general acceptance of the need to develop structures and improve regulations within the Ghanaian construction industry. However, the fragmentation of stakeholders has resulted in the absence of a clear agenda within the industry to address apparent problems that affect performance within the industry. Whilst there have been previous initiatives to help deliver industry-wide improvements in the Ghanaian construction industry, they have not received direct sustained attention from a single organisation with broad stakeholder participation. This undermines progress in the efforts to improve the overall environment and performance in the industry. This paper explores the development of a multi-stakeholder representative body for the Ghanaian construction industry to provide leadership in the pursuit of reform in the Ghanaian construction industry. The literature on developments within the global construction industry and industry initiatives to improve performance have been reviewed. This provides new pathways to ongoing efforts to achieve industry-wide regulation. It has been recognised in this paper that the ultimate objective towards the attainment of industrywide improvements in the Ghanaian construction industry remains the establishment of an Industry Development Agency.
\end{abstract}

Keywords: Construction, Industry development, Leadership, Ghana, Performance

\section{INTRODUCTION}

Previous studies show that the construction industries of developing countries such as Ghana face many problems (Badu et al., 2011; Fugar and Agyarkwa-Baah, 2010; Badu and Owusu-Manu, 2010; Platz, 2009; Abd El-Razek, Bassioni and Mobarak, 2008; Alaghbari et al., 2007; Sambasivan and Soon, 2007; Assaf and AlHejji, 2006; Martell and Guess, 2006; Frimpong, Oluwoye and Crawford, 2003; Frimpong and Oluwoye, 2003; Ahmed et al., 2003). These problems result in poor performance in the areas of cost, quality and productivity (Dogbegah, OwusuManu and Omoteso, 2011). For most construction projects undertaken in developing countries, the results fall short of the targets set by the participants themselves in terms of budgets (cost), schedules (time) and specifications (quality). The constructed items in these countries are also unsatisfactory in terms of their maintainability and durability (Ofori, 2012).

Department of Building Technology, Kwame Nkrumah University of Science and Technology, Kumasi, GHANA

*Corresponding author: kokuragu@yahoo.com

(C) Penerbit Universiti Sains Malaysia, 2016 
Performance in the Ghanaian construction industry is therefore a major cause of concern amongst client groups and other stakeholders. Ahadzie (2007) asserts that in many instances, contractors were blamed for poor performance and were criticised for having limited knowledge of the application of requisite management techniques. Qualifying this assertion, Vulink (2004) adds that construction firms do not employ personnel with the technical know-how to guide their firms towards sustainable growth. Consequently, poor management of resources - labour, financing, materials, plant and equipment - in Ghanaian construction does not promote growth (ibid.). In addition, the industry is described as "having a highly unstable business environment in which inflation eats the capital of contractors amongst other challenges which make it increasingly difficult to manage construction businesses" (Dansoh, 2005). The foregoing underlines serious problems associated with leadership within the Ghanaian construction industry. These constraints are, however, symptoms of a wider problem of the lack of a clearly defined agenda for the Ghanaian construction industry and the absence of appropriate platforms for organising the proposal and delivery of industry-wide improvements. As a result, there is very little collaboration between stakeholders in the public and private sectors, including Metropolitan, Municipals and District Assemblies (MMDAs), professional bodies - the Ghana Institution of Surveyors (GhIS), Ghana Institute of Architects (GIA), Ghana Institution of Engineers (GIE), Ghana Institute of Construction (GIOC) - and private firms. These professional bodies are usually weak in terms of enforcing rules, regulations and professional standards, partly due to the lack of a legal mandate membership is optional for most of these organisations The Ghanaian construction industry requires urgent leadership for the improvements that are generally required in the industry.

The move to establish the proposed Construction Industry Development Authority (CIDA) is progressing in the right direction (Ofori-Kuragu, Baiden and Badu, 2014). This was the product of a comprehensive study to establish an evidence-based proposition to support the arguments for a central agency to regulate the construction industry. This process is championed by the Chartered Institute of Building (CIOB) - Ghana and is funded by the Business Sector Advocacy Challenge (BUSAC) fund. As part of the process, a Steering Committee was established, composed of the Presidents of the Ghana Institution of Surveyors (GhIS), Ghana Institute of Architects (GIA), Ghana Institute of Planners (GIP), Ghana Contractors Association Council (GCAC), Ghana Institute of Technicians (GIT) and the Association of Building and Civil Engineering Contractors of Ghana (ABCECG). This paper aims at exploring new pathways to facilitate the attainment of the ultimate goal of establishing CIDA in Ghana by promoting the creation of an industry-driven industry council. The paper also seeks to outline proposals for establishing Ghana's Construction Industry Council.

The proposals are based on a review and discussion of lessons from construction industry developments globally, developments in the United Kingdom (UK) construction industry and examples from Hong Kong and Singapore. The paper is mainly based on a review of the extant literature. It is divided into three sections: first, we look at the dynamics of the Ghanaian construction industry, followed by a review of construction industry developments with a specific emphasis on the UK construction industry and examples from Hong Kong and Singapore; last, a discussion of lessons for Ghana from these industries is presented. 


\section{THE GHANAIAN CONSTRUCTION INDUSTRY}

The construction industry is very important to the economy of all nations. In Ghana, its contribution to the gross domestic product (GDP) has been approximately $8.2 \%$ per annum (Owusu-Manu and Badu, 2011), comparable to 8\%-10\% in the UK and other developed economies (Crosthwaite, 2000). In light of the significant progress made in many countries, including some African countries - taking South Africa as an example - it appears that Ghana is being left behind by developments in the effort to improve performance in the construction industry globally. A widespread culture of underperformance means that a majority of the major projects in Ghana are awarded to very few large firms, which are mostly foreign owned (Chileshe and Yirenkyi-Fianko, 2012; Tawiah, 1999).

A number of studies have identified the challenges of the construction industry. Ofori (2012) explored the problems that have affected Ghanaian construction firms. Some of the challenges identified as affecting these firms include the inability to secure adequate working capital, inadequate management, insufficient engineering capacity and poor workmanship. Badu, Edwards and Owusu-Manu (2012) noted that large and small contractors in Ghana have difficulty accessing financing for projects. Where debt financing is available, the interest rates tend to be very high. One consequence of this situation is a high frequency of abandoned projects. The cost in terms of lost time, re-engaging new construction firms, and reworking and repairing defects is high. For example, project delays lead to high escalations in costs owing to high inflationary trends.

Adams (2008) opined that delays in the payment of contractors for completed work are very common and constitute a major cause of delays in the completion of projects (Fugar and Agyarkwa-Baah, 2010). Heavy penalties are therefore levied against the government by courts. In an unusual development, a group of Ghanaian contractors resorted to street demonstrations to demand payment for completed government projects after several months of payment delays (Osam, 2012). On average, construction projects in Ghana recorded cost overruns of $60 \%$ to $180 \%$ and time overruns of between 12 and 24 months (Kpamma and Adjei-Kumi, 2010). There is also a lack of commitment towards the health and safety of Ghanaian construction workers, who work in generally unsafe environments (Ankomah, Boakye and Fugar, 2010). Only a small number of construction firms across the country, which are mostly foreign-owned, have the capacity to complete projects at a high standard of quality and excellence.

Laryea (2010) used the case study method to explore the challenges and opportunities that Ghanaian contractors face. The study involved detailed interviews and discussions with selected building and civil engineering firms and road contractors. The challenges identified for both groups of contractors were similar. They included difficulty accessing financing, payment delays, poor design quality, personnel issues, bribery and corruption, poor contractor classification, low workloads, cumbersome payment processes, the inability to compete in the competitive procurement system, lack of capacity to compete with foreignowned firms and fragmentation of contractor representation bodies. The other challenges are low technology levels, inadequate supervision of contracts, poor preparation for projects, revision of bills for quantities, politicisation of the contract bidding process and the lack of effective barriers to entry. 
Ofori-Kuragu (2014) ranked the problems that affect the performance of Ghanaian contractors using a survey of selected Ghana contractors. The survey identified the most critical factors affecting the performance of Ghanaian contractors as follows: (1) poor access to credit, (2) delays in payment from the government and government agencies, (3) cumbersome payment processes, (4) bribery and corruption in the construction industry, (5) contracts being awarded on the basis of one's political affiliation and (5) the processes involved in becoming a construction firm are too simple. Widespread perceptions and instances of corruption in the selection of contractors and awards of public projects have created serious image problems for the industry. The effects of these and many other problems are that it is difficult to attract investment into Ghanaian construction firms (Ghana Stock Exchange, 2012). In the decade up to 2012, there were no listed construction companies in the Ghana stock exchange and no Ghanaian construction firms in the Ghana Club 100 list of prestigious companies that demonstrate excellence in performance (Ghana Investment Promotion Centre, 2012).

A major feature of the Ghanaian construction environment is the separation between design and construction, with professionals tending to operate independently while giving allegiance to their respective professional bodies, such as the Ghana Institution of Architects (GIA), Ghana Institution of Engineers (GhIE) and Ghana Institution of Surveyors (GhIS). As a result, the adversarial relationships that traditionally characterise the construction industry in other countries are also very prominent in the Ghanaian industry (Ahadzie, 2007). Whilst the Ministry of Water Resources, Works and Housing and the Ministry of Roads and Highways are responsible for the classification of contractors, neither of the two ministries has any regulatory systems in place to monitor the performance of contractors or maintain the regulation of standards. Sanctions for non-performance of projects are not a sufficient deterrent measure for eliciting high standards of performance amongst contractors (Ofori-Kuragu, 2014).

Proposals to establish a central agency to coordinate the activities of these bodies and others are numerous (c.f. Ofori-Kuragu, 2014; Ofori, 2012; Daabu, 2012; Ofori and Toor, 2012). In a concerted effort by stakeholders, a thorough review of the construction industry was commissioned by $\mathrm{ClOB}$, Ghana and was funded by the Business Sector Advocacy Challenge Fund.

The Study on a Regulatory Agency for the Construction Industry in Ghana by Ofori-Kuragu, Baiden and Badu (2014) hinged on a baseline survey of stakeholders of the Ghanaian construction industry. This study confirmed the aforementioned challenges that were revealed by previous studies. As part of the scope of works that were agreed upon by stakeholders at a workshop for dialogue on 3 July 2014 and adopted by the Steering Committee, the report proposes the establishment of a Construction Industry Development Authority (CIDA) under the parentage of the Ministry of Water Resources, Works and Housing to "lead the regulation, restructuring, continuous improvement and development of the construction industry in Ghana, with the goal of enhancing the performance of the industry to derive optimum efficiency and effectiveness in its operations and outputs and to improve the quality of life of Ghanaians".

Under its purview, the CIDA shall be responsible for the construction industry which may be defined "as the part of the economy that plans, designs, builds, maintains, refurbishes, extends, and eventually demolishes buildings and 
infrastructure items of all types". The CIDA is therefore proposed as undertaking eight major activities:

1. championing and leading the regulation and strategic development of the construction industry,

2. advising the government on relevant aspects of the construction industry,

3. formulating regulations, standards and codes to guide practices and procedures and the nature of output in the construction industry,

4. registering contractors, consultants, and enterprises linked to the construction industry, such as suppliers of materials, and monitoring and controlling their performance,

5. proposing guidelines and frameworks to help streamline and promote good practices in both public and private organisations that are involved in the construction industry,

6. providing incentives to organisations to improve their performance,

7. collecting, processing, maintaining and disseminating information that is crucial for activities in the construction industry and

8. periodically determining the needs of the construction industry and formulating strategies and programmes for attaining them.

The Ghanaian construction industry can draw useful lessons from the experiences of other countries (Ofori et al., 2012). Benchmarking against countries with better developed industry structures will provide guidance on the way forward in the effort to achieve industry-wide organisational and project improvements in the Ghanaian construction industry. The next section reviews some global construction industry development initiatives.

\section{Possible Causes of Delay in Establishing Unified Body for Ghanaian Construction Industry}

The majority of existing work on the subject, such as Ofori (2012), Ofori et al. (2012), Donkor-Hyiaman (2014) and Ahadzie (2009), agree that Ghana has not made the expected progress in the effort to establish a unified body for the Ghanaian construction industry. Whilst there has been significant progress in developments globally and even in Africa, Ghana lags behind in this effort, even in the African context (Ofori et al., 2012). There is a natural expectation that the government will take the lead role in this regard; however, there is little evidence to suggest that the lack of a unified body such as Construction Industry Development Board (CIDB) for Ghana is due to resistance from the government. The lack of a unified body representing the Ghanaian construction industry may be due to the failure of leadership within the industry to unify industry efforts in the pursuit of a common agenda to establish an industry regulator. According to Ofori (2012), the lack of management for the improvement efforts, including the campaign for a unified body for the Ghanaian construction industry, have not received direct continuous attention and leadership from a single organisation. As a result, previous campaigns have been approached in a fragmented manner by professional groups without active widespread support and participation from across the industry. Some lead organisations that have championed previous efforts have not 
been considered truly representative of the overall industry and have not succeeded in generating significant industrywide support to enable the government to give the necessary support. For example, whilst Ofori (2012) praised the efforts of groups such as the Association of Building and Civil Engineering Contractors of Ghana (ABCECG) in the campaign for a unitary body, it is widely believed that the impact could have been stronger and that a government response could have been obtained more quickly if there had been greater industry involvement by recognisable professional groupings within the Ghanaian construction industry. Given the more broad-based approach in the recent past involving a coalition of professional groups representing civil engineers, architects, planners, and surveyors, amongst others, there is an increased likelihood of the success of current efforts.

It is also believed that the passage of the Engineering Council Bill of 2010 (Parliament of Ghana, 2015) may have indirectly affected the progress of efforts to establish a unified industry body for the Ghanaian construction industry. Some key stakeholders from within the Ghanaian construction industry have argued that the Engineering Council Bill sufficiently caters to the Ghanaian construction industry and thus do not see the need for another body for the construction industry. The obvious lack of support from all within the industry hampers the efforts even further. Thus, more work should be undertaken using the experiences in other counties to explain the key benefits that an industry-specific body for the Ghanaian construction industry would deliver.

\section{CONSTRUCTION INDUSTRY DEVELOPMENT}

Construction industry development has been described as a deliberate and managed process to improve the construction industry's capacity and effectiveness to meet the demand in national economies for building and civil engineering products and to support sustained national economic and social development objectives. Construction industry development promotes increased value for the money to industry clients as well as environmental responsibility in the construction delivery process. According to Ofori (2012), construction industry development also enhances the viability and competitiveness of domestic construction enterprises whilst optimising the role of all participants and stakeholders through process, technological, and institutional enhancement and appropriate human resource development.

Kumaraswamy (2006) suggested a strong correlation between construction industry development and infrastructure development. Across the construction industry, the failure to achieve the appropriate quality of construction is a global problem (FIDIC, 2006). There is widespread concern that the industry as a whole is underachieving (The Construction Task Force, 1998). As a response, many countries, especially in the developed world, have initiated programmes to improve the performance of their construction industries. Examples of performance improvement programmes include Australia's Building for Growth, Building and Construction Industries Actions Agenda of 1999, Finland's Reengineering the Construction Process Using Information Technology from 19972002, Japan's Future Directions of the Construction Industry programme of 1998 and Singapore's Construction 21. Other examples include South Africa's Creating

136/PENERBIT UNIVERSITI SAINS MALAYSIA 
an Enabling Environment for Reconstruction, Growth and Development in the Construction Industry campaign of 1997, the National Construction Goals in the United States of America (USA) and in Northern Ireland, Building Our Future Together and Achieving Excellence in Construction (AEC) of 1997 and 1999, respectively (Department of Finance and Personnel Northern Ireland, 2007).

Ofori (2012) identified four examples of industry development agencies in countries where they exist. These examples are ministries, government and quasigovernment agencies, and industry-funded agencies and advisory organisations. Industry-funded organisations and advisory organisations may also be government-controlled or quasi-government-controlled. This paper proposes an industry-funded organisation that is wholly initiated by the industry, with some collaboration from ministries and government agencies. Ofori (2012) proposed an action plan involving seven stages for the establishment of the CIDA:

1. A strategic and comprehensive review of the construction industry should be undertaken.

2. The general contents, recommendations and programme in this report should be widely debated among representatives of the stakeholders of the construction industry in Ghana.

3. The Government should appoint an inter-ministerial committee comprising representatives of all ministries that have a major interest in the construction industry, such as the Ministry of Water Resources Works and Housing (WRWH) and the Ministry of Roads and Highways.

4. A Focus Group should be formed to consider each of the broad categories of issues determined by the Task Team.

5. The Task Team should submit the detailed strategy of the Construction Industry Development Programme to the government.

6. A construction industry joint council to represent the interests of stakeholders of the industry development agency should be established. The Construction Industry Development Programme should be launched at a major event by either the Minister for WRWH or Minister for Roads and Highways.

7. CIDA should be set up to implement, co-ordinate and continuously monitor the industry development programme.

Whilst some of these steps have already been completed, other steps require action from the government or government functionaries over which the industry has little control. Any apprehension on the part of the government at any stage of the process can affect the action required and the overall progress. One school of thought opines that this may be the reason that the processes leading to the formation of an industry regulator have not made the expected progress. Hence, the proposal in this paper pushes for an industry to be initiated and industry-sponsored joint industry council to be established at an earlier stage to provide impetus and catalyse the formation of a national industry development agency. The Construction Industry Council (CIC) proposed for Ghana is modelled after the UK CIC, which was the first of many industry bodies established in the UK construction industry. 


\section{THE UK CONSTRUCTION INDUSTRY}

There were 194,025 construction firms in the UK in 2009, comprising 44,835 main trade construction firms and other trades making up the rest. Amongst the main trades firms, there are 10,629 non-residential construction firms, 27,791 residential construction firms and 6,415 civil engineering firms. The majority of the UK construction firms are small scale, with fewer than 20 employees. For example, in 2009, more than one-third of all construction firms in the UK had only one employee $(75,382$ firms), and more than two-thirds $(136,007)$ had between two and three employees. Altogether, $94.5 \%$ had between one and thirteen employees and $5.8 \%$ employed 14 to 79 people. The larger construction firms (more than 80 employees) made up $0.67 \%$ of the total, with less than $0.2 \%$ employing more than 300 people (ONS, 2010). The number of small firms in the UK construction industry is similar to those in Ghana, thus presenting opportunities to learn from the structure and organisation of the UK construction firms for the benefit of the Ghanaian industry.

The National Audit Office (2001) identified four major barriers to improving construction performance: procurement, problems associated with briefing and specification, design and planning and project management. Contractors, consultants and other industry players underbid as a means to obtain jobs. Poor briefings and definitions of requirements with insufficient focus on user needs and the functionality of the construction was also a problem. There is little integration of design and construction, contractors are not involved in the design process and the limited used of value management, standardisation and prefabrication are observed (National Audit Office, 2001). In comparison to other industries, the performance of the UK construction firms generally lags behind the performance of global leaders in terms of productivity, profitability, value added, investment in capital and research and development (R\&D) (Department for Business, Innovation and Skills, 2009). Despite the challenges faced by the UK construction industry, there are several positives that promote the industry's output. For example, the UK property sector receives a large amount of support from banks, such as property development loans; and mortgages, which account for about half of all corporate lending and provisions for loan defaults, with more than onefifth of commercial property borrowers breaching the terms of their loans or falling behind in their repayments (Duke, 2011). The availability of financing contributes largely to the vibrant property sector, which contributes significantly to the overall industry performance. There is a commitment to improvement, as observed in numerous industry initiatives and reports that are commissioned to investigate industry underperformance. These have led to the establishment of industry bodies, which address issues relating to the UK construction Industry. Some major developments in the UK construction industry are discussed next.

\section{UK Construction Industry Development}

The UK construction Industry has been a cause of concern at both the government and industry levels for more than half a century. A succession of industry reports have been initiated by successive governments in the UK, which are aimed at improving the construction process and output. These include the Emerson Report of 1962, the Banwell Report in 1964 and the Simon Report of 1994

138/PENERBIT UNIVERSITI SAINS MALAYSIA 
(Murray and Langford, 2003). Recently, however, the three most significant reviews are Latham (1994)'s Constructing the Team, the Levene Report and Egan's Rethinking Construction Report (National Audit Office, 2001). The most recent industry report, the Egan Report, describes the UK construction industry as having a low and unreliable rate of profitability, little investment in R\&D and low levels of capital. The report faults traditional procurement systems, which equate price to quality by selecting contractors and designers exclusively on the basis of tendered price and identifies a "crisis in training" (The Construction Task Force, 1998). In the case of training, it is reported that between 1994 and 1998, applications for construction-related courses operated by Universities for professional staff fell by 26\% (National Audit Office, 2001). The result is that there are few strategic, longterm shareholders in listed construction companies (Department of Environment, Transport and the Regions, 1998). Rethinking Construction built upon the Latham Report (Latham, 2004) and recommends that the construction industry learns from the experiences of industries such as the manufacturing and automobile industries that have achieved world-class excellence. The problems that necessitated the respective interventions in the UK are similar to those that the Ghanaian construction industry faces. Again, the Ghanaian construction industry derives its practice from the British construction industry (Ahadzie, 2007); thus, the choice of the UK as a case study for this paper.

\section{Evolution of the UK Construction Industry Structures}

Following Latham's Report of 1994, Constructing the Team and Egan's Rethinking Construction Report in 1998, several cross-industry bodies were established as part of the developments in the UK construction industry, such as:

1. The Construction Industry Board,

2. Reading Construction Forum,

3. Design Build Foundation,

4. Construction Best Practice Programme,

5. Movement for Innovation,

6. Government Construction Clients Panel,

7. The Housing Forum,

8. Local Government Task Force,

9. Rethinking Construction,

10. Constructing Excellence and

11. Construction Clients' Group.

(Construction Excellence, 2011)

The UK Construction Industry Board (CIB) was established in 1995 as a response to the Latham Report recommendations. It started with representatives from five "umbrella" bodies with the Minister for Construction as President. Other members included specialised trade federations, professional bodies representing contractors, sub-contractors, materials suppliers and construction clients (School of Construction and Property Management [SCPM], 2011). 


\section{The UK Construction Industry Council}

The respective contributions of the epochal Latham and Egan Reports on the development of the UK construction industry cannot be discounted. Significantly, however, the UK CIC had been established in 1988, long before these two major reports were released, to unify efforts and provide leadership in the drive to improve the UK construction industry $(\mathrm{CIC}, 2014)$. In the UK example, the $\mathrm{CIC}$ was the foremost body representing the industry from which $\mathrm{CIB}$ evolved. With members drawn from the respective professional groupings within the UK construction industry, the $\mathrm{CIC}$ is representative of professionals within the UK construction industry and serves as a common voice of construction professionals in relation to the government. The council's mission is to promote quality and sustainability in the established environment by providing leadership in the construction industry, encouraging a unity of purpose, collaboration, continuous improvement and career development $(\mathrm{ClC}, 2014)$. This could provide a blueprint for emulation in the Ghanaian industry. The role and functions of the UK $\mathrm{CIC}$ are similar to examples in other countries. The next section discusses two examples in Hong Kong and Singapore.

\section{LESSONS FROM OTHER COUNTRIES}

\section{Construction Industry Development in Hong Kong}

The Construction Industry Review Committee (CIRC) was set up as a follow-up to the Hong Kong Housing Authority (HKHA), which, prior to this point, had been mainly responsible for initiating and implementing initiatives in the construction industry and delivering ambitious housing programmes. The composition of the CIRC was composed of representatives of the government and various segments of the construction and property sectors, trade unions and universities with the vision of "an integrated construction industry that is capable of continuous improvement for excellence in a market-driven environment" (Ofori et al., 2012).

Following the establishment in 2000 of the Construction Industry review board (CIRC) to review the current state of the construction industry and to make recommendations for improvement, the "Construct for Excellence" report was produced in 2001. To address the fragmentation of the Industry and the prevailing adversarial culture, the report proposed the establishment of a statutory Industry Coordinating Body (ICB). The Provisional Construction Industry Co-ordinating Board (PCICB) was formed in September 2001 to champion the industry reform agenda and set the platform for the early establishment of the statutory ICB (HKCIC, 2012). Membership of the PCICB was mainly drawn from CIRC (Ofori et al., 2012).

\section{Construction Industry Council - Hong Kong}

The Hong Kong Construction Industry Council $(\mathrm{HKClC})$ serves as a resource centre for sharing knowledge and experience among stakeholders. It advises and serves as representatives to the Government on strategic matters, major policies and legislative proposals that may affect or are connected to the construction industry and on matters of concern to the construction industry (HKClC, 2012). The stated 
functions of $\mathrm{HKClC}$ include making recommendations based on the needs of the construction industry to the Government, promoting quality and competitiveness of the construction industry by facilitating ongoing development and improvement of the industry, promoting professionalism and integrity in the construction industry through the development of a voluntary code of conduct, and enforcing such codes whilst promoting self-regulation within the construction industry (HKCIC, 2012).

$\mathrm{HKClC}$ also serves to improve the performance of persons connected to the construction industry by establishing or administering registration schemes or rating schemes, working to advance the skills of personnel in the construction industry through the planning, promotion, supervision, provision or coordination of training courses or programmes, encouraging and promoting research activities and the use of innovative techniques, and establishing or promoting the establishment of standards for the construction industry. In addition to the above roles, the council is responsible for promoting best practices in the Hong Kong construction industry in procurement, project management, supervision, dispute resolution, sustainable construction and other areas that are conducive to improving construction quality and promoting harmonious labour relations as well as the observance of statutory requirements relating to employment to enhance the cohesiveness of the construction industry through the facilitation of communication among various sectors of the industry (HKClC, 2012). Other functions of $\mathrm{HKClC}$ include assessing improvements made by the construction industry through the development of performance indicators, making recommendations with respect to the rate of the levy imposed under the Construction Industry Council Ordinance and performing any other functions relevant to the construction industry, including functions conferred or imposed upon it by or under the Construction Industry Council Ordinance or any other enactment (HKClC, 2012).

\section{Construction Industry Joint Committee Singapore}

Formed in 1997, the Construction Industry Joint Committee (CIJC) unites key players in the construction industry and works closely with the singapore government towards improvement of the industry. Its eight members, according to Singapore Institute of Building (SIB) (2012), are the Association of Consulting Engineers Singapore, Institution of Engineers Singapore, Real Estate Developers' Association of Singapore, Singapore Contractors Association Limited, Singapore Institute of Architects, Singapore Institute of Building Limited, Singapore Institute of Surveyors and Valuers and Society of Project Managers. The member organisations work together towards the common goal of improving the construction industry in Singapore.

The stated objectives of CIJC include serving as a platform to unite all key players in the construction industry and coordinating efforts to upgrade the construction industry. This is to enable the organisation play a key role in the economy, providing quality feedback to the government on policies affecting the industry and problems encountered the sector and working in partnership with the government to develop appropriate solutions to the various problems affecting the industry (SIB, 2012). 
CIJC Singapore was formed following calls for the industry to take measures to improve its activities. The Council was formed, amongst other aims, to liaise with the respective sectors of Singapore's construction industry (Ofori, 1993). CIJC is a good model of an umbrella organisation that plays a championing role in industry development efforts whilst presenting a common voice in representing the needs of the Singapore construction industry to the government (Ofori, 2012).

Developments following the formation of the National Joint Council culminated in the establishment of a CIDB in 1984 (Ofori, 1993). Singapore's CIDB is cited as the most successful and the most studied model amongst the industry development agency initiatives globally (Ofori, 2012). It was formed to spearhead the expansion and development of the construction industry. In 1999, the CIDB was merged with the Building Control Division of the then-Public Works Department to form the Building and Construction Authority (BCA). Singapore's BCA is a government agency established under the BCA Act. It is an agency under the Ministry of National Development that champions the development of an excellent construction environment for Singapore. The stated functions of Singapore's BCA include promoting the development, improvement and expansion of the construction industry, including the use of advanced technology in the construction industry, advising the Government on matters relating to the construction industry, raising standards and efficiency in the construction industry by encouraging the standardisation and improvement of construction techniques and materials, providing consultancy and advisory services related to the construction industry, promoting the advancement of skills and expertise of persons in the construction industry, and increasing the professionalism and capabilities of firms in the Singaporean construction industry. Other functions of the BCA include the promotion of internationally recognised quality management systems in the Singaporean construction industry, facilitating the supply of essential construction materials, securing and managing land and facilities related to their import production, and carrying out research aimed at developing and improving the Singaporean construction industry (Ofori, 2012). Like the proposed CIC for Ghana, Singapore's example demonstrates the essential role that the industry can play in organising itself in anticipation of government support in the progression towards the formation of industry bodies.

Other examples of $\mathrm{ClCs}$ are found in Malaysia, where the Building Industry Presidents Council (BIPC) is a professionally driven, industry-recognised, government-endorsed body that provides leadership in the collective pursuit of excellence within the construction industry in Malaysia (GBI, 2012). Malaysia's BIPC is different from the CIDB of Malaysia which was established under an Act in 1994, whose objectives include promoting and stimulating the development, improvement and expansion of the construction industry, advising and making recommendations to the government on matters relating to the construction industry, promoting, stimulating and undertaking research into any matter with respect to the construction industry and the promotion of quality assurance in Malaysia relating to the construction industry. Other functions of BIPC are the promotion, stimulation and assistance in the export of construction industry-related services and providing consultancy and advisory services for construction industry (Ofori, 2012). According to Ofori (2012), the Malaysian CIDB was modelled after the Singaporean example. The Malaysian example typifies the model that is proposed for the Ghanaian construction industry.

142/PENERBIT UNIVERSITI SAINS MALAYSIA 


\section{African Successes}

Examples of how a unified body for the industry can champion improvement efforts in the construction industries of their respective countries exist in Africa. In South Africa, the CIDB was established by statute in 2001, amongst other things, to promote the contribution of the construction industry in meeting the national construction demand and promoting industry performance, efficiency and competitiveness. Its roles also include offering improved value to clients, providing strategic leadership to construction industry stakeholders to stimulate sustainable growth, reform and improvement of the construction sector as well as the determination and establishment of best practices that promote improved industry stability, industry performance, efficiency and effectiveness (Ofori, 2012). African countries such as Zambia, Rwanda, Malawi, Kenya and Tanzania all have central bodies for their construction industries that are backed by the state and are mainly responsible for the regulation and development of the industries (Donkor-Hyiaman, 2014). The key lesson to learn from the reviews of these countries' experiences is that giving legislative backing to these efforts helps provide the legal mandate and authoritative base for the work of these bodies.

\section{DISCUSSION: THE WAY FORWARD}

The experiences of many advanced countries showcase deliberate programmes and strategies to improve the management and delivery of construction within the industries in these countries. For example, the pursuit of improvement and excellence in the UK construction industry has led to a succession of major industry reports. If the Ghanaian construction industry achieves the type of progress that has been made by construction industries in other countries, innovative programmes are needed that will yield drastic changes and transform the industry from its current state to a level where it can deliver standards of excellence at a global level. Evidence from the literature on the UK construction industry reveals a well-regulated industry with regular reporting requirements such as annual reports, health and safety regulations, etc. The majority of UK construction companies are small scale, with less than $1 \%$ of the total contractor population employing more than 80 employees.

Egan's Rethinking Construction report identifies key challenges that the UK construction industry faces. These include low profitability, low investments in R\&D, a crisis in training, low levels of capital and the predominance of traditional procurement methods that use price as the basis for selecting contractors. The key barriers to performance within the UK construction industry are grouped into following four (4) categories: procurement, briefing and specific problems, problems with design and planning and project management issues. Rethinking Construction identifies benchmarking as presenting opportunities for improving performance in the construction industry. Again, the report identifies the key drivers that can lead to "dramatic improvements" in performance as follows: committed leadership, a focus on the customer, integrated processes and teams, a quality-driven agenda, and commitment to the people. Drawing lessons for the benefit of the Ghanaian construction industry, this paper believes that a multistakeholder representative body for the Ghanaian industry will provide crucial 
leadership and a platform to unite all critical factors that are identified as influencing performance improvements.

Leveraging the benefits of benchmarking, lessons are drawn from the structure and organisation of the UK construction industry to create proposals for the Ghanaian construction industry. Developments in the UK industry, such as the creation of the $\mathrm{CIC}$ and the $\mathrm{CIB}$, can be adapted for the Ghanaian construction industry. In the UK example, the CIC was the foremost body representing the industry from which the CIB evolved. With members drawn from the respective professional groupings, the UK CIC served as a common voice of construction professionals in relation to the government. This could provide a blueprint for emulation in the Ghanaian industry.

The respective compositions and functions of $\mathrm{CIC}$ and $\mathrm{CIB}$ are clearly distinct. Whilst the $\mathrm{CIC}$ is representative of professionals within the industry, the CIB maintains a regulatory function to ensure order within the industry. The clear distinction between the two bodies in terms of their respective form and functions justifies the need for these two vital industry groups. In terms of developing the industry further, the formation of Constructing Excellence in 2003 as the amalgamation of several previous initiatives and groupings confirms the relevance of a single point of responsibility for promoting excellence in the construction industry.

\section{The Ghanaian Construction Industry Context}

The available evidence shows a poor system of controls and regulation in the Ghanaian construction industry. There has recently been a welcome development of industry-led efforts to address standards in the industry. Initiatives include a campaign for the establishment of an industry regulator and the establishment of an industry-wide contractor's association. It is envisaged that this is the beginning of a movement towards greater organisation within the industry as a whole, which will lead to the development of structures and systems to address the numerous systemic problems that affect the Ghanaian construction industry.

It is recommended that industry-wide representative bodies be established to provide both regulatory and advocacy support to the industry. It is proposed that all major professional groups and stakeholders in the Ghanaian construction industry unite to form the Construction Industry Council, Ghana (CICG) to advance the collective interests of stakeholders within the Ghanaian construction industry.

\section{Objectives of the CIC}

It is proposed that, amongst other tasks, the CIC Ghana will:

1. provide a single voice for the Ghanaian construction industry,

2. provide a platform to unite key players in the Ghanaian construction industry,

3. provide vision, leadership and co-ordinate joint industry efforts to continuously improve the Ghanaian construction industry,

4. provide relevant feedback to the government on government policies and how they affect the Ghanaian construction industry,

144/PENERBIT UNIVERSITI SAINS MALAYSIA 
5. work with industry stakeholders to identify the problems that are present in the Ghanaian construction industry and provide leadership in addressing the problems,

6. serve as a think-tank for the industry and

7. work in partnership with the government to explore and seek common solutions to the problems affecting performance and delivery within the industry.

The proposed CICG is modelled after the UK construction Industry's CIC. Members may be admitted into one of three categories of membership as follows: Full Membership, Associate Membership or Honorary Affiliate Membership. Full Membership of the CICG will be open to Professional Institutions whose members are actively involved in planning, procuring, designing, constructing, regulating, maintaining or managing the built environment. Organisations within the construction industry that speak for defined groups but are not eligible for admission as full members of the Council may be admitted as Associate Members, whilst Honorary Membership may be conferred on individuals who have made substantial contributions to the Ghanaian construction industry. It is proposed that council members have a fixed term with an option to extend the mandate if the industry representatives so decide.

\section{CONCLUSION}

Available evidence on $\mathrm{CIC}$ shows this to be an industry-driven process. The proposed CICG will unite all major stakeholders within the industry with the common purpose of seeking improvements in the industry. The CICG will be a high level committee composed of representatives professional bodies within the Ghanaian construction industry. The Council will be responsible for initiating action to address critical issues that affect the Ghanaian construction industry. It will generally provide a voice for the industry in general policy issues and other matters for which individual firms lack the capacity to address by themselves. In such matters, the Council will act as an intermediary between the construction industry and the government whilst providing an advisory service to the government. It will provide both leadership and facilitate the establishment of relevant bodies as necessary in the common pursuit of excellence in the Ghanaian construction industry. This will include advocacy action for the establishment of an Industry Development Board for the Ghanaian Construction Industry. In this outline, proposals have been made for the establishment of the CICG. Potential founding members have been proposed for the Council. The next stage of this study will involve a sensitisation workshop for the potential members to collate their views on the proposals made in this paper and to discuss practical ways to realise these proposals. 


\section{REFERENCES}

Abd El-Razek, M.E., Bassioni, H.A. and Mobarak, A.M. (2008). Causes of delays in building construction projects in Egypt. Journal of Construction Engineering and Management, 134(11): 831-841. http://dx.doi.org/10.1061/(ASCE)07339364(2008) 134:11 (831).

Adams, F.K. (2008). Risk perception and Bayesian analysis of international construction contract risks: The case of payment delays in developing countries. International Journal of Project Management, 26(2): 138-148. http://dx.doi.org/10.1016/j.ijproman.2007.05.007.

Ahadzie, D.K. (2009). The Case for a Construction Industry Development Agency for Ghana. Available at: www.ghanaweb.com [Accessed on 20 October 2009].

Ahadzie, D.K. (2007). A model for predicting the performance of project managers in mass housing building projects in Ghana. PhD diss. University of Wolverhampton.

Ahmed, S.M., Azhar, S., Kappagntula, P. and Gollapudil, D. (2003). Delays in construction: A brief study of Florida construction industry. Proceedings of the 39th Annual ASC Conference. Clemson University, Clemson, South Carolina, 10-12 April, 257-266.

Alaghbari, W., Kadir, M.R.A., Salim, A. and Ernawati (2007). The significant factors causing delay of building construction projects in Malaysia. Engineering, Construction and Architectural Management, 14(2): 192-206. http://dx.doi.org/10.1108/09699980710731308.

Ankomah, B., Boakye, N.A. and Fugar, F. (2010). Safety on construction sites: The role of the employer and employee. Proceedings of the West Africa Built Environment Research (WABER) Conference. Reading, UK: University of Reading, 477-498.

Assaf, S.A. and AlHejji, S. (2006). Causes of delay in large construction projects. International Journal of Project Management, 24(4): 349-357. http://dx.doi.org/10.1016/j.ijproman.2005.11.010.

Badu, E., Edwards, P. and Owusu-Manu, D. (2012). Trade credit and supply chain delivery in the Ghanaian construction industry: Analysis of vendor interactions with small to medium enterprises. Journal of Engineering, Design and Technology, 10(3): 360-379. http://dx.doi.org/10.1108/ 17260531211274729.

Badu, E. and Owusu-Manu, D. (2010). Improving Access to construction finance in Ghana: Empirical descriptions of constraints and antidotes. Journal of Business and Enterprise Development, 2(1): 111-129.

Badu, E., Owusu-Manu, D., Edwards, D.J. and Holt, G.D. (2011). Innovative financing (IF) of infrastructure projects delivery in Ghana: Conceptual and empirical observations. Engineering Project Organization Journal, 2(2): 1-14.

Chileshe, N. and Yirenkyi-Fianko, A.B. (2012). An evaluation of risk factors impacting construction projects in Ghana. Journal of Engineering, Design and Technology, 10(3): 306-329. http://dx.doi.org/10.1108/17260531211274693.

Constructing Excellence. (2011). Construction KPIs 2011. London: Constructing Excellence. Available at: www.constructingexcellence.org.uk [Accessed on 30 December 2011 ].

146/PENERBIT UNIVERSITI SAINS MALAYSIA 
Construction Industry Council (CIC). (2014). Homepage. Available at: www.cic.org.uk [Accessed on 7 January 2015].

Construction Task Force. (1998). Rethinking Construction. London: UK Department of Trade and Industry.

Crosthwaite, D. (2000). The global construction market: A cross-sectional analysis. Construction Management and Economics, 18(5): 619-627. https://doi.org/10.1080/014461900407428.

Daabu, A.M. (2012). Contracts for Oil Infrastructure Awarded. Accra, Ghana: myjoyonline.com. Available at: www.myjoyonline.com [Accessed on 7 August 2012].

Dansoh, A. (2005). Strategic planning practice of construction firms in Ghana. Construction Management and Economics, 23(2): 163-168. http://dx.doi.org/10.1080/0144619042000241435.

Department for Business, Innovation and Skills (DBIS). (2009). The 2009 Value Added Scoreboard. London: DBIS.

Department of Environment Transport and the Regions (DETR). (1998). Rethinking Construction. London: DETR.

Department of Finance and Personnel Northern Ireland (DFPNI). (2007). Northern Ireland Guide to Expenditure Appraisal and Evaluation. Belfast, Northern Ireland: DFPNI. Available at: www.eag.dfpni.org.uk [Accessed on 20 October 2007].

Dogbegah, R. Owusu-Manu, D. and Omoteso, K. (2011). A principal component analysis of project management competencies for the Ghanaian construction industry. Australian Journal of Construction Economics and Building, 11 (1): 26-40. http://dx.doi.org/10.5130/ajceb.v11i1.1680.

Donkor-Hyiaman, K.A. (2014). Towards establishing the "construction industry development authority" in Ghana. Modern Ghana, 18 July. Available at: https://www.modernghana.com/news/557132/towards-establishing-theconstruction-industry-development.html [Accessed on 28 October 2015].

Duke, S. (2011). Lenders face loss on loans to property. Daily Mail, 18 March, 31.

Frimpong, Y. and Oluwoye, J. (2003). Significant factors causing delay and cost overruns in construction of groundwater projects in Ghana. Journal of Construction Research, 1(2): 175-187. http://dx.doi.org/10.1142/S16099451 03000418.

Frimpong, Y., Oluwoye, J. and Crawford, L. (2003). Causes of delay and cost overruns in construction of ground water projects in developing countries: Ghana as a case study. International Journal of Project Management, 21 (1): 321-326. http://dx.doi.org/10.1016/S0263-7863(02)00055-8.

Fugar, F.D.K. and Agyakwah-Baah, A.B. (2010). Delays in building construction projects in Ghana. Australian Journal of Construction Economics and Building, 10(1 \&2): 103-1 16. http://dx.doi.org/10.5130/ajceb.v10i1/2.1592.

Ghana Investment Promotion Centre (GIPC). (2012). Top 100 Companies in Ghana 2011. Accra, Ghana: GIPC. Available at: www.gipcghana.com [Accessed on 20 June 2012].

Ghana News Agency (GNA). (2012). Construction of Oil Infrastructure to Begin. Accra, Ghana: GNA. Available at: www.ghananewsagency.org [Accessed on 7 August 2012]. 
Ghana Stock Exchange (GSE). (2012). Listed Firms on the Ghana Stock Exchange. Accra, Ghana: GSE. Available at: www.gse.com.gh [Accessed on 20 May 2012].

Green Building Index (GBI). (2012). Homepage. Available at: www.greenbuildingindex.org [Accessed on 15 November 2012].

Hong Kong Construction Industry Council (HKCIC). (2012). Homepage. Available at: www.hkcic.org [Accessed on 15 November 2012].

International Federation of Consulting Engineers (FIDIC). (2006). Quality of Construction. Geneva: FIDIC. Available at: www.fidic.org [Accessed on 30 August 2006].

Kpamma, Z. and Adjei-Kumi, T. (2010). The Lean Project Delivery System (LPDS): Application at the design and documentation stage for construction projects in Ghana. Proceedings of the West Africa Built Environment Research (WABER) Conference. Reading, UK: University of Reading, 597-604.

Laryea, S. (2010). Challenges and opportunities facing contractors in Ghana. Proceedings of the West Africa Built Environment Research (WABER) Conference Ghana. Reading, UK: University of Reading, 215-226.

Latham, M.S. (1994). Constructing the Team. London: Her Majesty's Stationery Office (HMSO).

Martell, C. and Guess, G.M. (2006). Development of local government debt financing markets: Application of a market-based framework. Public Budgeting and Finance, 26(1): 88-119. http://dx.doi.org/10.1111/j.15405850.2006.00840.x.

Kumaraswamy, M.M. (2006). Accelerating construction industry development. Journal of Construction in Developing Countries, 11 (1): 73-94.

Murray, M. and Langford, D., eds. (2003). Construction Reports 1944-98. Oxford: Blackwell Science Ltd.

National Audit Office. (2001). Modernising Construction. London: The Stationery Office.

Office for National Statistics (ONS). (2010). Construction Statistics Annual 2010. Newport, South Wales: ONS. Available at: http://www.statistics.gov.uk/ downloads/theme_commerce/CSA-2010/Opening.pdf [Accessed on 18 November 2010].

Ofori, G. (2012). Developing the Construction Industry in Ghana: The Case for a Central Agency. Singapore: National University of Singapore.

Ofori, G. (1993). Managing Construction Industry Development: Lessons from Singapore's Experience. Singapore: National University of Singapore Press.

Ofori, G., Ai Lin, E. and Tjandra, I. (2012). Construction industry development initiatives: Lessons for Ghana from overseas. International Conference on Infrastructure and Development. Kumasi, Ghana: College of Architecture and Planning, Kwame Nkrumah University of Science and Technology, 1217.

Ofori, G. and Toor, S. (2012). Leadership and construction industry development in developing countries. Journal of Construction in Developing Countries, 17(Supp. 1): 1-21.

Ofori-Kuragu, J.K. (2013). Enabling world-class performance in Ghanaian contractors: A framework for benchmarking. PhD diss. Kwame Nkrumah University of Science and Technology.

148/PENERBIT UNIVERSITI SAINS MALAYSIA 
Ofori-Kuragu, J.K., Baiden, B. and Badu, E. (2014). Factors affecting Ghanaian contractor performance. Proceedings for the CIB W107 2014 International Conference. Lagos, Nigeria: International Council for Research and Innovation in Building and Construction, 275-285.

Osam, I.E. (2012). Danger on Construction Site. Available at: www.citifmonline.com [Accessed on 28 February 2012].

Owusu-Manu, D. and Badu, E. (2011). Capital Structure, Investment Strategy And Financial Decisions: The Perspective of Large Construction Enterprises in Developing Countries. Saarbrücken, Germany: Lambert Academic Publishing.

Parliament of Ghana. (2015). Engineering Council Bill 2010. Available at: http://www.parliament.gh/assets/file/Bills/Engineering\%20Council\%20Bill,\%20 2010.pdf [Accessed on 12 October 2015].

Platz, D. (2009). Infrastructure finance in developing countries: The potential of subsovereign bonds. DESA Working Paper No. 76ST/ESA/2009/DWP/76, July. New York: Department of Economic and Social Affairs (DESA), United Nations. Available at: http://www.un.org/esa/desa/papers/2009/wp76_2009.pdf [Accessed on February 2011].

Sambasivan, M. and Soon, Y.W. (2007). Causes and effects of delays in Malaysian construction industry. International Journal of Project Management, 25(5): 517-526. http://dx.doi.org/10.1016/j.jpproman.2006.11.007.

School of Construction and Property Management (SCPM). (2011). Homepage. Available at: www.revaluingconstruction.scpm.salford.ac.uk/ [Accessed on 4 November 2011 ].

Singapore Institute of Building (SIB). (2012). Homepage. Available at: http://www.sib.com.sg/site [Accessed on 14 November 2012].

Tawiah, O. (1999). Factors affecting the performance of Ghanaian owned construction firms. MSc diss. Kwame Nkrumah University of Science and Technology.

Vulink, M. (2004). Technology transfer in the construction industry of Ghana. MSc diss. Technische Universiteit Eindhoven. 